\title{
Natural Resources and Government Responsiveness
}

\section{David Wiens}

\begin{abstract}
Pogge (2008) and Wenar (2008) have recently argued that we are responsible for the persistence of the so-called "resource curse". But their analyses are limited in important ways. I trace these limitations to their undue focus on the ways in which the international rules governing resource transactions undermine government accountability. To overcome the shortcomings of Pogge's and Wenar's analyses, I propose a normative framework organized around the social value of government responsiveness and discuss the implications of adopting this framework for future normative assessment of the resource curse and our relationships to it.
\end{abstract}

Social scientists often claim that countries with an abundance of exportable point-source natural resources (e.g., oil, natural gas, copper) are more likely to be governed by authoritarian regimes (Ross, 2001; Wantchekon, 2002) and suffer economic dysfunction (Auty, 2001; Sachs and Warner, 1995). This so-called "resource curse" is a moral disaster. Many of the afflicted countries contain a significant percentage of the global poor. ${ }^{1}$ These countries are often riven by civil conflict, and their residents are harried and left destitute by corrupt leaders who prioritize personal aggrandizement over providing their citizens with basic public goods, such as law enforcement or public infrastructure.

Thomas Pogge (2008) and Leif Wenar (2008) have recently argued that we - the citizens of developed democracies and our government officials - are partly responsible for this disaster. Pogge's and Wenar's normative analyses are organized around the social value of government accountability. In supporting an international rule that permits dictators to conclude legally valid resource transactions, we promote unaccountable

Author's note. Earlier versions of this paper were presented at the 2nd Annual Dutch Conference on Practical Philosophy and to an audience in the political science department at the University of Michigan; thanks for participants for profitable discussions. Special thanks to Elizabeth Anderson, Bill Clark, Matt Golder, Sona Golder, Holly Lawford-Smith, Paul Poast, Jennifer Rubenstein, Leif Wenar, and Scott Wisor for helpful discussion. Support from the Social Sciences and Humanities Research Council of Canada (award \#752-2007-0083) is gratefully acknowledged.

1 Resource-cursed countries comprise more than 300 million poor people, nearly a quarter of the 1.4 billion people who live below the World Bank's \$1.25/day poverty line-almost half of the global poor if we exclude China and India. This statistic is lower than it should be since the poverty data for Libya, Myanmar, and Sudan - all populous resource rich countries with high poverty rates - are missing. Poverty data from UNDP 2008.

(C) 2013 David Wiens

Penultimate version. Definitive version to appear in Politics, Philosophy and Economics. 


\section{David Wiens}

governance and its associated deprivations in many resource rich countries. We are thus morally responsible for the resource curse and, accordingly, bear stringent obligations to reform the offending institutions.

I argue that Pogge's and Wenar's analyses are limited in important ways. Using a model of state-citizen bargaining, I show that a preponderance of resource revenues in a country's political economy can affect the extent to which a government is responsive to citizens' interests in two ways. The first is by reducing the government's need to collect revenue from citizens; the second is by reducing the credibility of citizens' threats to withhold support from the government. Fulfilling either of these conditions is sufficient to precipitate a resource curse. I then show that Pogge's and Wenar's analyses neglect the second of these factors at two critical points. First, in concentrating on the international rules governing resource transactions, Pogge and Wenar miss the fact that a resource curse can persist even after we reform those rules, since they do not affect citizens' exit options. ${ }^{2}$ Second, in focusing on the ways in which international rules undermine government accountability, Pogge and Wenar overlook the fact that credible exit threats are a necessary condition for the emergence of the sort of institutional accountability they emphasize. As a result, Pogge's and Wenar's analyses give us a limited grasp of the resource curse and our relationship to its persistence.

To avoid these shortcomings, I present a normative framework organized around the social value of government responsiveness. Responsiveness is both more general and more basic than Pogge's and Wenar's accountability (I defer discussion of the differences to section 4). Crucially, my proposed framework can attend to the value of Pogge's and Wenar's accountability while also accounting for the causal and normative significance of citizens' exit options. Attention to responsiveness prompts us to look beyond our relationship to resource transactions and the international rules that govern them, taking a wider view of the myriad ways in which we potentially contribute to the persistence of unresponsive government in resource rich countries, in particular, the ways in which we limit curse victims' exit options. This wider view might bring under scrutiny (e.g.) our immigration policies and non-resource-related trade policies. Although I do not offer a positive normative assessment here, restructuring our normative framework as I propose is a necessary prelude to analyzing the resource curse in a way that is sensitive to the full

2 It is natural to think of "exit" as synonymous with "emigration". To forestall worries based on this thought, I wish to not that “exit option" is being used in Hirschman's (1970) more general sense of "taking one's business elsewhere". In other words, an exit option (in the sense relevant here) is an opportunity to withhold (e.g., fiscal, electoral, military) support from a state's governing authority (cf. Clark, Golder and Golder, 2013). I discuss exit options in more detail below. 
range of causally and normatively salient factors.

\section{EXPLAINING THE RESOURCE CURSE}

Although political economists disagree about the causal mechanisms that generate the resource curse, there does seem to be widespread agreement that the nature of a country's domestic institutions plays a crucial role in explaining its emergence.

With respect to the negative effect resource wealth has on the prospects for democracy - the political resource curse - two types of explanation predominate. One strand of literature focuses on the idea of a "rentier state", in which resource revenues discourage democratization by freeing governments from the need to raise revenue via taxation (Karl, 1997; Mahdavy, 1970; Ross, 2001). Without the need to elicit citizens' tax compliance, political leaders need not negotiate with citizens over policy. ${ }^{3}$ Further, low tax rates alleviate social pressures that might otherwise provoke demands for government accountability (Ross, 2004). Consequently, leaders who receive a sizeable income from resource extraction have few incentives to accept institutional limits on their exercise of political power. Without the need to collect taxes from a broad swath of the populace, it is also the case that leaders do not have to develop an efficient and disciplined bureaucracy, further weakening fiscal oversight. Finally, resource revenues might enable governments to appease citizens' demands for redistribution, diminishing redistributive pressures that could produce calls for democracy (Dunning, 2008; Morrison, 2007, 2009). In sum, resource revenues enable political leaders to preempt the emergence of causal processes that generate pressure for governments to democratize.

Another strand of literature highlights the ways in which resource revenues facilitate authoritarian leaders' efforts to consolidate their hold on political power (Jensen and Wantchekon, 2004; Smith, 2006; Wantchekon, 2002). When political leaders monopolize resource rents, they gain a sizeable "incumbent advantage" in securing political support. Leaders can use resource revenues to preempt opposition through patronage. Or, anticipating opponents' need to resort to unconstitutional means to break this advantage, incumbents can use revenues to build coercive power, which they can then employ to repress political opposition. In either case, incumbent leaders' discretion over resource revenues sustains authoritarianism by providing leaders with sufficient means to resist pressure to democratize and consolidate their hold on political power.

3 Throughout the paper, I use "leader", "ruler", "government", and "state" to refer to the agent who retains the ultimate power to implement or block the implementation of policy, as well as the loyal bureaucrats to whom particular tasks are delegated. 
There are subtle differences between these two strands of theory, but these need not detain us here. Underlying both stories is a common theme-namely, that resource revenues diminish the prospects for democracy by forestalling or aborting causal processes that might otherwise culminate in the consolidation of institutional mechanisms designed to hold incumbent leaders accountable to competing groups in civil society. This suggests that, where institutional mechanisms to hold leaders accountable to citizens are established prior to the flow of resource rents, increased resource revenues need not lead to democratic retrenchment. Put differently, although resource revenues diminish the likelihood that nondemocracies will democratize, they need not reduce a democracy's chances of remaining democratic.

This focus on institutions also underlies much recent work on the economic resource curse - the thesis that resource wealth is detrimental for a country's economic performance. Given that democracy is associated with better economic performance (Gerring et al., 2005), the fact that resource wealth diminishes the prospects for the emergence of democracy implies that it will, in turn, diminish a country's economic prospects (cf. Collier and Hoeffler, 2009). The economics literature further highlights the ways in which resource rents encourage incumbent leaders to take advantage of a lack of institutional constraints on their discretionary power to allocate revenue in ways that hinder or subvert economic productivity. Where institutions fail to promote accountability and state competence, resource revenues can decrease economic productivity by encouraging incumbent leaders to, in an effort to retain power, divert revenue away from economically productive investments toward economically unproductive forms of patronage, such as public sector jobs (Robinson, Torvik and Verdier 2006). Many economists also argue that, where domestic institutions permit, resource wealth encourages "rent-seeking" - that is, it encourages efforts to secure a share of resource wealth by manipulating the social and political environment rather than by contributing to the production of that wealth. This has a negative effect on economic performance because it diverts both human and financial resources away from economically productive uses (Mehlum, Moene and Torvik, 2006).

In sum, according to the most recent work on the resource curse, the effect of resource wealth on political and economic development is conditioned by the nature of domestic institutions. If a resource rich country has institutions that fail to curtail the government's discretionary power, especially its control over resource revenue spending, then resource wealth has a negative effect on development. Otherwise, resource wealth can be developmentally beneficial. This assessment is encouraged by examples of resource rich countries that have managed to avoid the curse - Norway and Canada are 
prime examples. Prior to discovering huge oil reserves, these countries had established institutions that encourage government accountability and, consequently, policies that advance citizens' interests. Accordingly, prescriptions for addressing the resource curse have focused on reforming domestic institutions (e.g., Humphreys, Sachs and Stiglitz, 2007). The thought supporting these prescriptions is a natural one: if the curse arises from domestic institutional failures, then we would avert the resource curse if we could improve domestic institutions in the relevant ways.

\section{NORMATIVE ASSESSMENTS OF THE CURSE}

Thomas Pogge and Leif Wenar have built upon these empirical analyses in their recent normative assessments of the resource curse. The general lesson both draw from their reviews of the relevant literature is that resource rich countries are cursed because institutional failures permit resource revenues to fall into the wrong hands: "The resource curse is not a curse that falls on poor countries because they have abundant resources. [...] The blessing of resources turns into a curse when tyrants and insurgents are allowed to sell off a country's resources while crushing popular resistance, and to use the proceeds in ways that make the people worse off" (Wenar, 2008: 8, 9). ${ }^{4}$

But both Pogge and Wenar think that the standard explanations neglect an important consideration, namely, the extent to which international rules regulating trade in resources causally contribute to the persistence of the failed institutions that allow resource revenues to fall into the wrong hands. The main culprit is what Pogge calls the "international resource privilege", which grants the power to effect legally valid resource transfers to any person or group holding a monopoly on the use of effective force in the territory containing the resources in question. When it comes to international resource transfers, the resource privilege ensures that "might makes right" (Wenar, 2008: 13).

Pogge's and Wenar's normative assessments center on the international resource privilege because it is "both suspect in principle and pernicious in its consequences" (Wenar, 2010: 132). It is suspect in principle because it permits unaccountable governments to sell off a territory's natural resources without citizens' consent. It is pernicious in its consequences because, by affording governments discretionary control of resource revenues, it establishes an incentive structure that engenders political and economic dysfunction. On this point, the story is a relatively simple if sparse one (see Pogge 2008: 119-120; Wenar 2008: secs. I \& II). By holding out the prize of a reliably large revenue stream, the resource privilege creates incentives for predators to acquire and wield power

4 Cf. Pogge (2008: 119-120, 169-172). 
violently. Once in power, predatory rulers are free to use the revenue to buy arms and political support to keep themselves in power, even against widespread opposition. Even reform-minded rulers, if they want to stay in office, are compelled to divert resource revenues to the private fortunes of the political elite or to keeping potential rebels at bay. As Wenar notes, such clientelism facilitates widespread corruption and hinders effective development investment, which helps explain economic dysfunction.

This assessment yields two different arguments for the claim that the persistence of the resource privilege is unjust. The first, emphasized by Wenar, argues that the resource privilege is akin to a rule that treats thieves as holding legitimate title to stolen goods - it effectively treats predators as the legitimate owners of natural resources and permits them to conclude resource transactions without citizens' consent, thereby violating citizens' property rights in their country's natural resources. Hence, our enforcement of the resource privilege is unjust because it violates a duty to respect citizens' property rights (Wenar, 2008: sec. III). ${ }^{5}$ The second, emphasized by Pogge, argues that, by upholding the resource privilege to promote their own economic advantage, rich and powerful countries are at least partly responsible for the persistence of unaccountable governance and, consequently, the vast misery associated with it. Given feasible alternatives to the status quo, our enforcement of the resource privilege is unjust because it violates a duty not to impose foreseeable and avoidable harm (Pogge, 2005a, 2007).

To be precise about the nature of Pogge's and Wenar's criticisms, note that there are two distinct sites at which we can normatively assess the resource curse - transactions and institutions. To illustrate the distinction, consider the difference between assessing instances of theft and assessing a rule that, for arbitrary reasons, prevents members of a racial minority from owning property. In the former, we assess the extent to which transactions violate principles of justice; in the latter, we assess the extent to which institutions violate principles of justice. Similarly, with respect to the resource curse, we might judge that individual transactions that put resource revenues in the hands of authoritarians are unjust because they foreseeably visit grave harm upon ordinary citizens at the hands of predatory dictators (with Pogge), or violate citizens' property rights (with Wenar). Thus, those who engage in such transactions - the agents of countries and firms that purchase resources or territorial concessions from authoritarians - do so unjustly because their actions violate clear principles of justice - that we ought not

5 Wenar cites numerous legal documents - both international and domestic - to support citizens' claim to rightful ownership of the resources in their territory: Article 1 of the two International Covenants (on Civil and Political Rights and on Economic, Social, and Cultural Rights); Article 21 of the African Charter on Human and Peoples' Rights; Iraqi and Angolan domestic law; as well as various UN resolutions and declarations. 
impose foreseeable and avoidable harm on others and that we ought to respect property rights. With respect to institutions, we might judge that the resource privilege is unjust because it generates an incentive scheme that foreseeably induces negligent, corrupt, and sometimes violent characters to acquire and exercise power to the detriment of ordinary citizens (with Pogge), or confers de facto legitimacy upon resource transactions brokered by predatory dictators, which violates citizens' property rights (with Wenar). Thus, not only do individual resource transactions with authoritarians violate clear principles of justice, but the rule that grants legitimate title to authoritarians, and our enforcement of it, is also unjust because $i t$ violates our duty to not impose foreseeable and avoidable harm or to respect property rights.

Although Pogge and Wenar undoubtedly lament the transactions that generate the resource curse, their criticisms focus intently on institutions. This is clearly so for Pogge, whose criticism is part of a long-standing program aimed at showing that global poverty results from unjust international institutions; the resource privilege is a recurrent example of how the "global institutional order" harms the global poor. Although Wenar discusses transactions more than Pogge does, his institutional focus is clear. A focus on market transactions is, in Wenar's words, a "misdirection of attention from the institutional to the natural"; the resource curse "results from a failure of institutions: specifically, a failure to enforce property rights" (Wenar, 2008: 8, 9, my emphasis).

Their differences aside, both Pogge's and Wenar's assessments find the resource privilege problematic because it permits unaccountable governments to control the stream of revenues derived from resource extraction. The straightforward solution, then, is to replace the resource privilege with a rule that effectively prevents unaccountable governments from controlling resource revenue. To bolster their cases for the claim that the resource privilege is an unjust rule, both Pogge and Wenar propose what they take to be feasible institutional reforms aimed at keeping resource revenue out of the hands of unaccountable governments.

Pogge proposes an "amend-and-adjudicate" strategy (as I'll call it). His proposal has two main components. First, fledgling democracies whose economies depend heavily on resource exports should amend their constitutions to include a clause that declares resource transfers executed by future authoritarians illegitimate (Pogge, 2008: 169). By putting investors on notice that the resource transfers negotiated with authoritarians will be challenged should democracy be restored, the amendment aims to deter investment in resource extraction under authoritarians. Without more or less stable investment demand, resources become less valuable to would-be dictators, thereby reducing the size of the prize awaiting those who successfully acquire political power by unconstitutional 
means. This is expected, in turn, to reduce the number of attempts to acquire power unconstitutionally, thereby helping to consolidate democratic reforms. To ensure that the deterrent effect of the amendment isn't undermined by authoritarians who simply suspend the amendment, Pogge proposes the establishment of a "Democracy Panel". This is "an international panel, composed of reputable, independent jurists living abroad who understand [the country's] constitution and political system well enough to judge whether some particular group's acquisition and exercise of political power is or is not constitutionally legitimate" (Pogge, 2008: 162). This “adjudication” part of Pogge's proposal is meant to restore investors' confidence in their title to resources acquired from legitimate governments. Unless obtained from a government that is determined illegitimate by the panel, investors have no reason to worry about the legitimacy of their title to the resources. This is supposed to restore the incentives to invest in extraction under democratic regimes while diminishing those same incentives under nondemocratic regimes.

The crux of Wenar's proposal is to prohibit resource transfers that take place without citizens' valid consent. At a minimum, respecting citizens' property rights requires a government to acquire "some sort of valid consent" from its constituents when transferring resources (Wenar, 2008: 20). To give valid consent, citizens must have at least minimal civil and political rights. As an authoritative standard for determining whether citizens have the requisite rights, Wenar employs the widely-used Freedom in the World report, a rating of countries according to their respect for civil and political rights published by Freedom House. ${ }^{6}$ To create "the strongest legal framework", he makes the least controversial assumptions possible: a Freedom House rating of " 7 " — the lowest possible rating - on either civil liberties or political rights is "decisive indication that no regime can legitimately sell resources from that country" (Wenar, 2008: 25). To enforce this legal framework domestically, Wenar proposes to grant standing to the citizens of a resourcecursed country to bring civil suits against resource corporations in the latter's domestic courts. ${ }^{7}$ Alternatively, resource corporations could be tried domestically for the crime of receiving stolen goods. ${ }^{8}$ Successful civil or criminal cases against resource corporations would help enforce citizens' resource rights by deterring the former from dealing with predatory regimes. To enforce the proposed property rights regime internationally, Wenar proposes what he calls a "trust-and-tariff" trade policy. The "tariff" part of the proposal

6 For details on the Freedom House ratings, see http:/ / www.freedomhouse.org.

7 Wenar cites three cases as precedent: Doe v. Unocal, 2003 WL 359787 (9th Cir.); WIWA v. Royal Dutch Petroleum Co. \& Shell Transport and Trading Co., WL 319887 (S.D.N.Y. 2002); and Kensington v. PNP Parnibas, 05 Ci. 5101 (LAP) (S.D.N.Y. 2005).

8 Wenar cites the National Stolen Property Act (18 USC 2314) and the extraterritorial jurisdiction of a Federal statute on the receipt of stolen goods (18 USC 662) as support for this litigation strategy. 
requires compliant states to identify defector states - i.e., states who host resource corporations that deal with illegitimate governments or states who have direct such dealings of their own - and levy tariffs on imported goods coming from defectors. Insofar as the tariff harms the competitiveness of defector state firms in compliant state markets, the tariff serves as a punishment for acquiring resources from predatory regimes and aims to deter future such acquisitions. Once an illegitimate regime comes to power, compliant states should establish a "Clean Hands Trust" for the citizens of the resource-cursed state. This trust fund would be filled by the proceeds from the tariffs levied by compliant states against defector state imports until the fund's principal equals the value of the resources illegitimately transferred from the predatory government to defector states. The money in the fund is then held for the citizens of the resource cursed country until the minimum conditions for legitimate resource transfers are met. Once these conditions are met, the money (the fund's principal plus interest) is transferred to the citizens of the resource cursed country (or, perhaps more accurately, their legitimate representatives).

While it would be worthwhile to scrutinize the feasibility of each of these proposals, I wish to leave this issue aside. ${ }^{9}$ Instead, I want to interrogate the extent to which our assessment of the resource curse should focus on the international resource privilege. Below, I will argue that, by focusing so intently on the resource privilege, both Pogge's and Wenar's normative analysis obscures an important dimension of the resource curse - namely, the ways in which resource assets undermine citizens' bargaining leverage vis-a-vis the state. Hence, their analyses give us a limited grip on the resource curse and our relationship to it. Attention to the full range of factors underwriting citizens' bargaining leverage has important implications for our normative analysis. But before I discuss these, we must revisit our causal diagnosis of the curse.

\section{EXPLANATION REVISITED}

Recall the main lesson of section 1: resource revenues diminish a country's political and economic development prospects by forestalling or aborting causal processes that might otherwise culminate in the consolidation of institutional mechanisms designed to hold incumbent leaders accountable to competing groups in civil society. This suggests that resource revenues need not undermine positive development outcomes where institutions to limit governments' discretionary power are entrenched prior to the flow of resource rents.

9 Wenar (2010) challenges the feasibility of Pogge's proposal; Wisor (2012) poses feasibility challenges for Wenar. 
Two key questions arise here for those who seek to explain the resource curse. First, under what conditions do political leaders accept institutions that limit their exercise of political power and hold them accountable to citizens? Second, how do resource revenues affect the causal processes that culminate in such institutions? I take these questions in turn.

One venerable explanation for the rise of institutional constraints on government power appeals to political leaders' need to make credible commitments to prospective supporters. Political leaders typically require support from some subset of their constituents to retain political power, be it as a source of revenue, votes, or military assistance to defeat a rival. To secure their support, leaders offer policy concessions to those whose support is necessary for retaining office. But without any mechanism to bind the leader to follow through on his promises, prospective supporters have little assurance that the leader will deliver as promised. As Myerson (2008: 125) puts it, "a successsful leader needs a reputation for reliably rewarding his supporters" (my emphasis). In the absence of a credible commitment, prospective supporters will rationally discount the leader's offer. But if potential supporters' alternative to cooperating with the leader - placing their money in investments that elude taxation, voting for a challenger, engaging in armed rebellion - promises to be more valuable than the discounted value of the leader's offer, then supporters can credibly threaten to withhold their support if the leader fails to keep his promise. Hence, if the required supporters have credible "exit threats" (Hirschman, 1970), the leader must solve a commitment problem to attract the necessary support. To overcome this problem, the leader implements institutional mechanisms that constrain him to follow through on his promise and, thus, raise the credibility of his offer. The classic case here is the consolidation of parliamentary supremacy in England following the Glorious Revolution of 1688 (North and Weingast, 1989; Tilly, 1992). But the dynamic is supposed to be quite general, applying to both democracies and dictatorships. When political leaders require cooperation from constituents, they are induced to bargain over policy with prospective supporters. When those supporters can credibly threaten to withhold support, political leaders must accept institutional constraints on their control over future policy decisions in exchange for political support in the present (cf. Acemoglu and Robinson, 2006; Bates and Lien, 1985; Bueno de Mesquita et al., 2003; Levi, 1988).

To better understand the structural conditions underwriting these institutional bargains, consider a general situation where a government confronts a citizen who can choose whether to deploy his assets within the government's jurisdiction. ${ }^{10}$ Suppose that,

10 The following paragraphs draw on work done in collaboration with William Roberts Clark, Matt Golder, Sona Golder, and Paul Poast. 
historically, the citizen has invested in the government's jurisdiction and that his gross income, $Y$, has been taxed by the government at a low rate, $\tau_{L} \geq 0$; the citizen's net per period income has been $Y-\tau_{L} Y=\left(1-\tau_{L}\right) Y$. However, the government has maintained unsupervised discretion over fiscal policy. Until now, the revenue derived from taxing the citizen at the low rate, $\tau_{L} Y$, has been sufficient to cover the government's obligations. But suppose that the government's fiscal needs now exceed $\tau_{L} Y$. This increased need could arise for any number of reasons; for example, the government might need to increase defense spending to confront a military challenge; it might need to provide economic stimulus when an economic recession threatens; perhaps it must provide aid to citizens affected by a natural disaster. In any case, in light of its increased fiscal need, the government is now considering implementing a higher tax rate, $\tau_{H}>\tau_{L}$. Whether the government implements the tax hike depends on the citizen's expected response to the increase. The citizen can respond by disinvesting, objecting to the tax hike, or continuing to invest. The basic structure of the interaction is shown in figure $1 .{ }^{11}$

Suppose the government implements the tax hike. If the citizen continues to invest, then his net per period income is his gross income minus the taxes he pays at the high rate, $\left(1-\tau_{H}\right) Y$, while the government's per period tax revenue is $\tau_{H} Y$. If the citizen disinvests, the government receives $\tau_{H} Y$ for the current period, but loses access to the expected stream of future revenues that would have been generated by the asset holder's continued investment. ${ }^{12}$ Disinvestment means that the asset holder receives $\left(1-\tau_{H}\right) Y$ for the current period, as well as the expected stream of income generated by his exit payoff, $E$. The citizen's exit payoff is the return net of any taxes on the second best use of his asset, which could involve consumption or investment in some other asset or jurisdiction. I assume that $E<\left(1-\tau_{L}\right) Y$; if this were not the case, then the asset holder would have disinvested prior to the period under consideration.

Finally, if the asset holder objects to the continued implementation of the higher tax rate, he pays a cost, $C>0 .{ }^{13}$ The government can respond to an objection by (i) ignoring it or (ii) reverting to the low tax rate for the current and all future periods. In the first case, where the government ignores the objection, the asset holder either makes good on his threat to disinvest (which is at least implicit in his objection to the tax hike) or he

11 The model under consideration is a game theoretic adaptation of Hirschman's (1970) "Exit, Voice, and Loyalty" model. Citizens' options can be naturally characterized as exit, voice, and loyalty, respectively. See also Clark, Golder and Golder (2008, 2013); Wiens (forthcoming).

12 The idea here is that it takes one period for investors to redeploy their assets, so that the government can benefit in the short run from confiscatory tax rates.

13 This captures the intuition that protesting, lobbying, complaining, or taking direct action all require resources (time, effort, money) that could be put to an alternative use. 


\section{David Wiens}

Figure 1. Exit, Voice, and Loyalty (EVL) Resource Curse Game

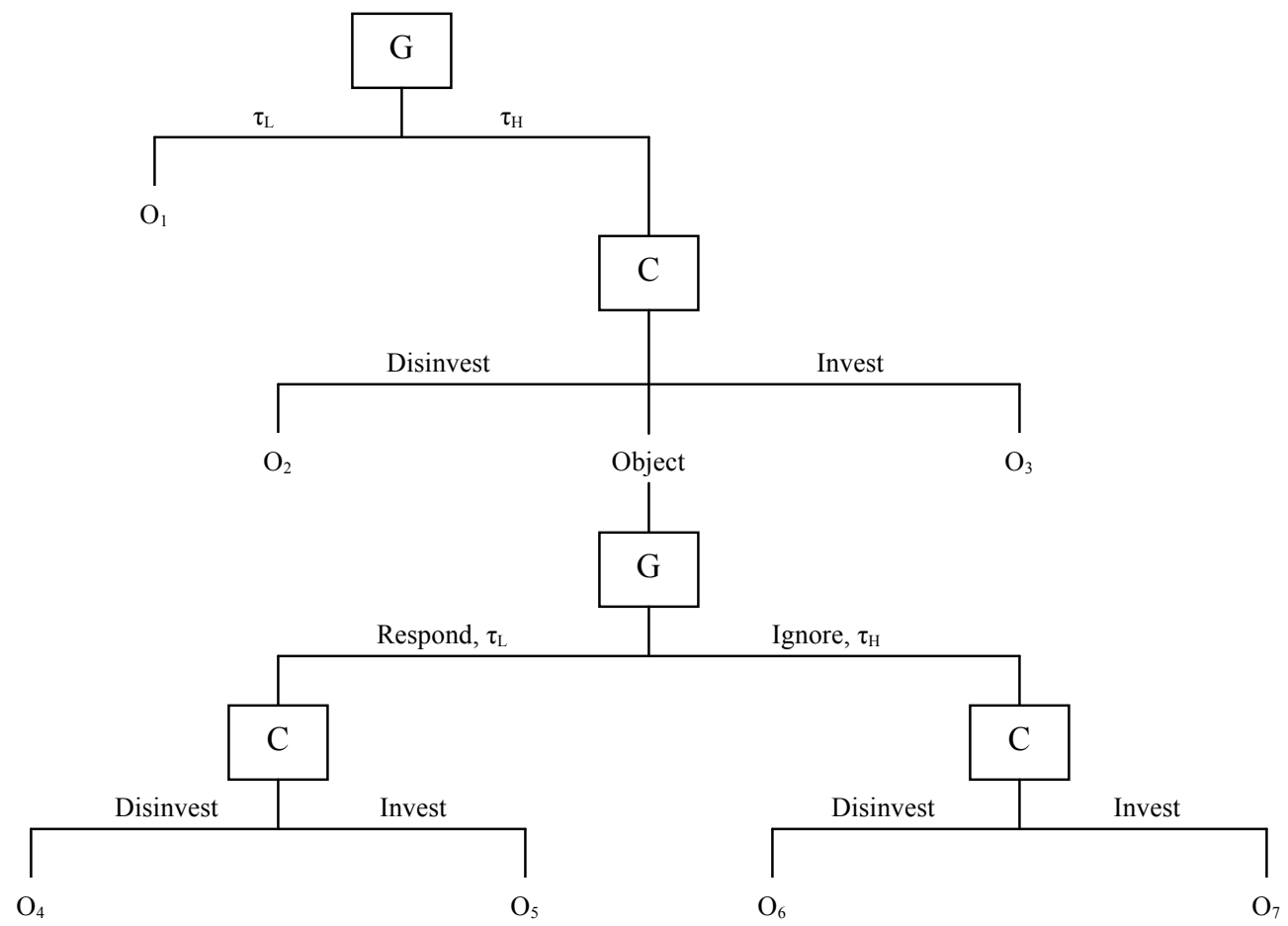

\begin{tabular}{cll|cll} 
Outcome & Government & Asset Holder & Outcome & Government & Asset Holder \\
\hline $\mathrm{O}_{1}$ & $\tau_{L} Y+\sum_{t=1}^{\infty} \delta^{t}\left(\tau_{L} Y\right)$ & $\left(1-\tau_{L}\right) Y+\sum_{t=1}^{\infty} \delta^{t}\left(1-\tau_{L}\right) Y$ & $\mathrm{O}_{5}$ & $\tau_{L} Y+\sum_{t=1}^{\infty} \delta^{t}\left(\tau_{L} Y\right)$ & $\left(1-\tau_{L}\right) Y-C+\sum_{t=1}^{\infty} \delta^{t}\left(1-\tau_{L}\right) Y$ \\
$\mathrm{O}_{2}$ & $\tau_{H} Y$ & $\left(1-\tau_{H}\right) Y+\sum_{t=1}^{\infty} \delta^{t} E$ & $\mathrm{O}_{6}$ & $\tau_{H} Y$ & $\left(1-\tau_{H}\right) Y-C+\sum_{t=1}^{\infty} \delta^{t} E$ \\
$\mathrm{O}_{3}$ & $\tau_{H} Y+\sum_{t=1}^{\infty} \delta^{t}\left(\tau_{H} Y\right)$ & $\left(1-\tau_{H}\right) Y+\sum_{t=1}^{\infty} \delta^{t}\left(1-\tau_{H}\right) Y$ & $\mathrm{O}_{7}$ & $\tau_{H} Y+\sum_{t=1}^{\infty} \delta^{t}\left(\tau_{H} Y\right)$ & $\left(1-\tau_{H}\right) Y-C+\sum_{t=1}^{\infty} \delta^{t}\left(1-\tau_{H}\right) Y$ \\
$\mathrm{O}_{4}$ & $\tau_{L} Y$ & $\left(1-\tau_{L}\right) Y-C+\sum_{t=1}^{\infty} \delta^{t} E$ & & & \\
\hline
\end{tabular}

Note: The game comprises two players: (i) the government, $G$, and (ii) the asset holder, $A$. The asset holder's payoffs depend on his pre-tax income from the first best use of his asset, $Y$; the expected return on the second best use of his asset, $E$; his discount factor, $\delta$; the cost of objecting to any government tax hike, $C$; and whether the tax rate is low, $\tau_{L}$, or high, $\tau_{H}$. The government's payoffs depend on the asset holder's pre-tax income from the first best use of his asset, its discount factor, and the tax rate. We assume that $\tau_{H}>\tau_{L} \geq 0, E<\left(1-\tau_{L}\right) Y$, and that $0<C<\left(\tau_{H}-\tau_{L}\right) Y$. 
continues to invest at the high tax rate. If he disinvests, the asset holder receives $\left(1-\tau_{H}\right) Y$ in the current period and receives his exit payoff in future periods, while the government receives $\tau_{H} Y$ in the current period but forfeits the stream of tax revenues that would have been generated by the asset holder's continued investment. If he continues to invest, the asset holder receives $\left(1-\tau_{H}\right) Y$ in the current period and a future per period income of $\left(1-\tau_{H}\right) Y$, while the government receives $\tau_{H} Y$ in every period, including the present. In the second case, where the government reverts to the low tax rate, the asset holder can again choose to either disinvest or continue investing. If he disinvests, the asset holder receives $\left(1-\tau_{L}\right) Y$ in the current period and receives his exit payoff in future periods, while the government receives $\tau_{L} Y$ in the current period and loses access to the ongoing stream of tax revenues that would have been generated by the asset holder's continued investment. If he continues to invest, the asset holder receives $\left(1-\tau_{L}\right) Y$ in every period, while the government receives $\tau_{L} Y$ in every period.

Equilibrium behavior in this game depends on relatively few parameters. ${ }^{14}$ I restrict my attention to the situation where the cost of objecting is low enough that the citizen has an incentive to object to a tax increase rather than simply disinvest immediately. There are two scenarios of particular note, one where the citizen does not possess a credible exit threat and one where he does. The citizen possesses a credible exit threat whenever he has a worthwhile alternative to continuing to invest in the government's jurisdiction at the high rate, i.e., $E>\left(1-\tau_{H}\right) Y$.

Scenario 1: Citizen lacks a credible exit threat. If $E \leq\left(1-\tau_{H}\right) Y$, the citizen's expected income from continuing to invest at the high rate is at least as great as the expected income from his exit option. Hence, he continues to invest even if the government ignores his objection. Given this and the fact that $\tau_{H} Y>\tau_{L} Y$, the government never reverts to the low tax rate if the citizen objects to the tax hike. Since objections are costly and ignored, the citizen never objects to the tax hike. Lacking a credible exit threat, the citizen responds to an increase in the tax rate by maintaining his current level of investment. Consequently, the government implements the tax hike.

Scenario 2: Citizen has credible exit threats. Since $E>\left(1-\tau_{H}\right) Y$, the citizen disinvests if the government ignores his objection to the tax hike and continues to invest only if the government responds to his objection by reverting to the low tax rate. There are two subcases of interest depending on how much value the government places on continued investment. The government values continued investment if and only if $\delta \geq 1-\frac{\tau_{L}}{\tau_{H}}$. Hence,

14 Proofs for the results in this section are left to an online appendix. 
the government places sufficiently high value on continued investment if and only if its discount rate on future income is sufficiently high, i.e., if and only if the inequality holds. When this condition does not hold, the government places more value on the one time revenue increase generated by the tax hike than the stream of future revenues produced by the low tax rate, and therefore ignores any objection from the citizen. Knowing this, and given his credible exit threat, the citizen simply disinvests when the tax hike is introduced. When the government places sufficiently high value on continued investment, it values the stream of future revenues produced by the low tax rate more than the one time revenue increase generated by the tax hike. Given this, and knowing that the asset holder will disinvest if the high rate is in force, the government maintains the current low tax rate. ${ }^{15}$

According to this analysis, the outcome of the bargaining interaction depends on two parameters: the extent to which the government values the citizen's continued investment and the credibility of the citizen's threat to disinvest, which turns on the value of the citizen's outside investment option. In this particular case, the government is likely to be constrained in its selection of the tax rate only if it values citizens' continued investment and it confronts citizens who can credibly threaten to invest elsewhere, i.e., citizens who have credible exit threats.

To avoid confusion, it is worth pointing out that we can generalize the logic of the analysis by noting that nothing in the model requires that we understand "exit threat" in investment terms. We could have instead positive a generic adverse policy shift and characterized the citizen's options as withdrawing support from the government (exit), objecting to the policy change (voice), and continuing to support the government despite the change (loyalty) (cf. Clark, Golder and Golder, 2013). As a non-investment related example, take a democratic government considering a policy change that will adversely affect some of its citizens. Affected citizens can lobby for a policy change (voice), vote for another candidate in the next election (exit), or stay silent and vote for the incumbent (loyalty). If the government requires electoral support from some number of the adversely affected citizens in the next election, ${ }^{16}$ the logic of the model says it will be responsive

15 Strictly speaking, the government is indifferent between not imposing the tax hike and imposing the tax hike but immediately reverting to the low tax rate once the asset holder objects. To avoid knife-edge scenarios, I assume that the government chooses not to impose the tax increase at the initial stage if it knows it will revert at a later stage. I could, instead, assume that the government pays a small cost for reneging on a public policy declaration; I decline to do so for the sake of simplicity.

16 This suggests an important qualification of the analysis: the government will be sensitive to citizens' interests generally only if one of two conditions is satisfied: (1) the government relies on the support of a large and diverse coalition of citizens (Bueno de Mesquita et al., 2003), or (2) if the government relies on a small 
to those citizens' interests only if they can credibly threaten to vote for a challenger in the next election. The key to the logic, as Hirschman (1970) puts it, is competition: governments are responsive to citizens only if there is competition for political power, that is, only if citizens have alternatives to supporting the incumbent. Hence, the term "exit threat" is mean to cover, quite generally, a wide range of strategies that citizens might deploy in response to adverse policy shifts in their environment. I focus on the fiscal case here because it is more salient for analyzing the resource curse.

Returning to the investment case, the analysis thus far only demonstrates the conditions under which governments are constrained in the selection of the tax rate. I haven't yet shown how, or why, a government might be induced to accept formal institutional limits on its fiscal policy discretion under the specified conditions. The suggestion above was that they accept institutional limits on their future policy discretion as a commitment device to assure citizens with credible exit threats that it will not arbitrarily impose confiscatory tax rates. If the government implements institutions that empower citizens to punish governments who arbitrarily impose confiscatory tax rates, then citizens can be assured some measure of control over future fiscal policy, thereby limiting the government's capacity to engage in arbitrary confiscation. Consequently, they continue to invest.

For the purposes of understanding the resource curse, I need not elaborate the details of this commitment story any further. The government faces a commitment problem - and, hence, accepts institutional limits on its policy discretion - only if it seeks to extract additional revenue from citizens who can credibly threaten to disinvest at the high tax rate. Meeting its increased fiscal needs is no problem when the government faces citizens without alternative investment options; I have already shown that the government can increase taxes with impunity in this case. In virtue of their physical and economic characteristics, point-source resources such as oil and copper are paradigmatic cases of assets that leave their holders with relatively low value investment alternatives. ${ }^{17}$ First, point-source resource extraction is especially capital and technology intensive, requiring massive initial investments to exploit the resources profitably. Since anyone who has made the required initial investments will be reluctant to abandon them before they

elite for support, the government's best strategy for retaining elites' support requires the provision of public goods, which benefit everyong (for example, to foster economic growth in an effort to raise the tax revenue required to satisfy the elites' demands) (Clark et al., 2010). These qualifications are fully consistent with the thrust of the discussion in the main text. I return to this in my discussion of government responsiveness below. For a more detailed discussion, see Wiens (forthcoming).

17 What follows owes much to Snyder and Bhavnani's (2005) discussion of "nonlootable" vs. "lootable" resources. 
are able to recoup their costs, holders of resource assets will be especially vulnerable to predatory taxation. Second, extractive resource assets are fixed; quite simply, oil wells and copper mines can't be moved. Holders of resource assets can't credibly threaten to take their enterprise elsewhere when faced with predatory tax rates. ${ }^{18}$ Third, extractive activity is relatively easy for the government to monitor. The high economic barriers to entering the resource sector mean that few firms will be able to extract resources profitably; the fixity of resource assets means that resource firms cannot easily hide extractive activity from government inspection. All this means that resource extraction can be easily monitored by the state, reducing asset holders' ability to hide profits from tax authorities. Fourth, resource extraction generates huge profits relative to many other sectors; hence, governments can impose extremely high tax rates on resource firms without fear of inducing disinvestment. ${ }^{19}$ In view of these characteristics, holders of point-source resource assets have relatively low value investment alternatives. Put in more general terms, holders of point-source resource investments lack credible exit threats.

When a government's power is not checked by institutional limits and the economy is dominated by asset holders without exit options - as in resource rich dictatorships - we should not expect the government to accept the types of institutional limits on their power that are necessary for positive political and economic development - namely, institutions that enable constituents to check policy selection and empower them to replace incumbents who neglect to implement development-enhancing policies. In the absence of such institutions, political leaders are free to neglect citizens' interests and use resource revenues in ways that further erode political competition and undermine economic productivity. Yet, the analysis also suggests that where institutions do limit leaders' exercise of power, resource revenues need not pose a developmental challenge. This is why countries such as Canada or Norway have been able to avoid the resource curse. These countries had already consolidated democratic institutions prior to the inflow of high resource revenues. Thus, their citizens can respond to adverse policy shifts by credibly threatening to withhold support from an incumbent governments - they have credible exit threats.

Extant analyses of the resource curse emphasize the effect of resource revenues on leaders' reliance on citizens' support. By providing leaders' with a reliable non-tax revenue stream, resource extraction decreases a leaders' reliance on citizens as a source

18 Someone has suggested to me that asset holders could threaten to destroy the resource stock. But this isn't a credible threat. Even if resource holders are left with little after state predation, that's still more than nothing.

19 For example, Venezuela taxed away $78 \%$ of foreign oil firms' profits by 1970 (Karl, 1997: 112). 
of revenue; by facilitating repression, resource revenues decrease leaders' reliance on citizens' voluntary cooperation with their rule to retain power; by facilitating patronage, resource revenues enable leaders to appease citizens' demands for decent economic opportunities, thereby thereby decreasing leaders' reliance on economically productive citizens as catalysts for providing those opportunities (see section 1). These analyses tacitly suggest that resources cause political and economic dysfunction only if resource revenue flows directly to the state's coffers. Not surprisingly, extant prescriptions concentrate on diminishing governments' discretionary control over resource revenues (by increasing transparency of revenue flows, for example) or taking resource revenues out of the hands of unaccountable governments altogether. Pogge's and Wenar's proposals take the second approach, mandating sanctions on resource exports from authoritarian countries (see section 2).

Standard empirical analyses rightly note that reducing political leaders' reliance on citizens as a source of revenue is sufficient to increase the likelihood of political and economic dysfunction; I don't wish to dispute that resource revenues can diminish leaders' reliance on citizens' support in the aforementioned ways. Instead, I deny the adequacy of an analytic framework that focuses predominantly on this aspect of the resource curse. The analysis in this section shows that, to reduce the likelihood of a curse, leaders must rely on citizens with credible exit threats. Absent credible exit threats, even a dependent leader can extract from citizens with impunity. Extant analyses obscure the fact that citizens' lack of credible exit threats is also sufficient to increase the likelihood of a curse. Attending to citizens' exit options yields an analysis of what happens were extant prescriptions to actually reduce leaders' discretionary control over resource revenues. The verdict is not necessarily a positive one; economic and political dysfunction can persist in resource rich countries even when leaders must rely on citizens as a source of revenue because the nature of assets held in countries dominated by extractive resources undermines citizens' bargaining leverage vis-a-vis the state. ${ }^{20}$ Hence, existing analyses of the resource curse obscure an important dimension of the resource curse. An adequately rich analysis of the curse must account not only for the effect of resource revenue on leaders' reliance on citizens, but also its effect on the credibility of citizens' exit threats.

20 Indeed, a savvy dictator could get around the sanctions proposed by Pogge and Wenar without much loss by simply turning over state-owned resource assets to private citizens. Without credible exit threats, the dictator could tax away much of the resource profits without fear of inducing disinvestment. 


\section{REVISING OUR NORMATIVE FRAMEWORK}

Pogge's and Wenar's assessments of the resource curse are built upon empirical analyses that focus on the role that resource revenues play in undermining political leaders' reliance on their citizens. Their diagnostic contribution is to expose the role of international rules - in particular, the international resource privilege - in maintaining this state of affairs. Yet, by concentrating their analyses on the resource privilege and its role in permitting unaccountable governments to control resource revenue, Pogge and Wenar account for only one dimension of the resource curse - namely, the role of resource revenues in reducing political leaders' reliance on citizens. But keeping money out of unaccountable governments' hands is only part of the story. A sufficiently rich normative framework for assessing the resource curse must also attend to the credibility of citizens' exit threats. Moreover, focusing on the resource privilege obscures the causal salience of citizens' exit threats. This is because the resource privilege is not linked to those physical and economic characteristics that undermine fixed asset holders' threats to take their enterprise elsewhere. Indeed, no institution - domestic or international-can be charged with the fact that resource assets are fixed or that their profitable extraction is capital and technology intensive and easy to monitor. Altering these characteristics is beyond institutional reform. Since it neglects and obscures the causal role of exit options, the normative lens through which Pogge and Wenar assess the resource curse is of limited use.

Pogge's and Wenar's assessments suffer a second limitation, which requires some elaboration. Normatively, both analyses are structured around the social value of government accountability. This isn't immediately apparent; at a glance, Pogge's analysis is centered on human rights against severe deprivation, while Wenar's seems to focus on property rights. But a look below the surface reveals that government accountability plays a key organizing role for both.

For Wenar, the resource privilege is normatively problematic because it violates basic principles of "ownership and sale", in particular, the rule that "to make a valid sale a vendor must either be the owner or have the owner's authorization" (Wenar, 2008: 16, 17). Since citizens are the rightful owners of the resources in their country's territory (Wenar, 2008: sec. III), a government must obtain authorization from its subjects for the sales it concludes to be valid. To authorize a sale, citizens must at least: "(1) be able to find out about the sales; (2) be able to stop the sales without incurring severe costs; and (3) not be subject to extreme manipulation by the seller" (Wenar, 2008: 20). Put simply, a government can conclude valid resource transactions - i.e., citizens' property rights are upheld - only if it is accountable to its citizens, at least so far as resource transactions are 
concerned. Government accountability with respect to resource transactions also serves to organize Wenar's proposed reform: governments that cannot be credibly deemed to have authorization from citizens - i.e., unaccountable governments - are subject to trade sanctions; domestic firms who buy resources from unaccountable governments are liable to face lawsuits in domestic courts; foreign countries who purchase resources (or who host firms who purchase resources) from unaccountable governments are subject to "Clean Hands" trade tariffs; and the money collected from these tariffs is returned to the country from which the resources were purchased only once accountable governance is restored.

Government accountability plays a similarly central role for Pogge. On his view, a human right against deprivation requires that institutions protect reasonably "secure access to minimally adequate shares of basic freedoms and [political] participation, of food, drink, clothing, shelter, education, and health care” (Pogge, 2008: 57). Normatively, the problem with the resource privilege is that it undermines the institutional protections required to fulfill individuals' basic human rights by accommodating and even promoting unaccountable governance in resource rich countries. Pogge's proposed solution emphasizes the need to improve democratic accountability in resource exporting countries: resource transactions concluded by nondemocratic governments are liable to legal challenge, while resource transactions are valid only if concluded by sufficiently democratically accountable governments.

We should note that Wenar restricts his analysis to government accountability with respect to resource transactions, which is less comprehensive than Pogge's democratic accountability. $^{21}$ Despite this difference, they share a single notion of accountability, namely, that of institutionally guaranteed opportunities for citizens to exercise effective voice, emphasizing citizens' capacity to shape policy through free, fair, and competitive elections and their freedom to dissent. Governments are sufficiently accountable when institutions protect citizens' capacity to express their individual preferences and beliefs without fear of repression and require that they be taken as inputs for collective decisions (Pogge 2008: 152f, 190; Wenar 2008: 20, 25).

Put in these terms, we can readily see a limitation of Pogge's and Wenar's assessments: they emphasize citizens' capacity to exercise voice but ignore citizens' ability to exit. This is problematic for two reasons. In the first place, it neglects exit as an important means

21 Wenar (2010: 137) describes the difference here as one of distinct "grounding values", Wenar's property to Pogge's democracy. Since citizens' property rights are upheld, for Wenar, to the extent that governments are accountable to citizens with respect to resource sales, we can translate Wenar's distinction to a difference in the scope of the relevant domain of government accountability. 


\section{David Wiens}

by which citizens can influence political decisions. Second, and more importantly, it overlooks the fact that credible exit threats are a necessary condition for effective voice, especially in the absence of democratic institutions. This is a key implication of the model in section 3 - in the absence of credible exit threats, governments have little incentive to heed citizens' voice. ${ }^{22}$ Exit options are a precondition for the emergence of the sort of institutional accountability Pogge and Wenar emphasize. Indeed, if the model captures causally important features of the situation in resource rich countries, then the lack of accountability Pogge and Wenar criticize is a symptom of citizens' lack of credible exit threats.

In sum, Pogge's and Wenar's analyses neglects citizens' exit options at two critical points: in selecting the resource privilege as the target of their normative assessments and in selecting accountability as their assessments' organizing value. These shortcomings recommend an alternative normative framework, one that attends to the full range of causally salient variables, as well as the full range of means by which citizens can influence policy.

To structure future assessment of the resource curse, I propose that we adopt a normative framework centered on the social value of government responsiveness. Let's say a government is broadly responsive to the extent that it advances citizens' general interests in response to citizens' actual or expected conduct. Three features are worth noting. The first is that responsiveness is a continuous variable; it is a matter of degree. Second, a government is broadly responsive to the extent that it selects policies that advance the interests of citizens generally and not just the interests of a small political and economic elite. Among other things, a responsive government accepts institutional limits on its exercise of power, is sensitive to a broad and diverse range of interests, and provides public goods that that lead to more or less broadly distributed economic gains. ${ }^{23}$ In contrast, an unresponsive government represses political challenges and pursues the private interests of the ruling elite. Third, a broadly responsive government advances citizens' interests because, given leaders' interests, it is constrained to do so by citizens' conduct. Put differently, a responsive government advances citizens' interests because, given citizens' actual or anticipated conduct, advancing citizens' interests is a better strategy for advancing leaders' interests than failing to do so. This last feature is key. A

22 Cf. Warren (2011: 684), who argues that "exit and voice do not trade off" because the former pertains to the "empowerment of individuals" while the latter pertains to individuals' "communication of values and preferences" (original emphasis).

23 See footnote 15 and the citations therein for discussion on the conditions under which governments are broadly responsive. 
government is not necessarily responsive if it advances citizens' interests out of goodwill or public spiritedness (although it might be commendable for doing so); a government is responsive only if it advances citizens' interests because it is constrained by citizens to do so. (I drop the "broad" qualification hereafter.)

Responsiveness is clearly related to Pogge's and Wenar's accountability, but it is more general. Citizens' institutionally protected exercise of voice is neither necessary nor sufficient to ensure responsiveness, as shown in section 3. Further, accountable governments are responsive, but not all responsive governments are accountable. For example, autocratic governments might adopt growth-enhancing economic policies for fear of capital flight or citizens' withdrawal from the labor market or mass protest. Responsiveness is also a more basic value than accountability, in the sense that it is a constituent of accountability. Among others, one reason we value accountable government is because we value responsive government. Institutionally protecting citizens' exercise of voice is but one way to ensure responsiveness. ${ }^{24}$ Responsiveness is also more basic in that it is an empirical precondition for the manifestation of Pogge's and Wenar's institutional accountability: governments accept institutions that make them accountable to citizens only if they are responsive.

A normative framework organized around the value of responsiveness can account for the factors underwriting Pogge's and Wenar's accountability while also attending to the causal and normative significance of citizens' exit options. This is because responsiveness is manifest whenever conditions are such that a government's exercise of political power is constrained by citizens, by whatever means available. Unlike Pogge's and Wenar's analyses, a normative framework centered on responsiveness is sensitive to both of the parameters highlighted in the model above: the extent to which leaders' depend on citizens' support and the extent to which citizens can credibly threaten to withhold that support.

I'm not arguing that our assessment should disregard the resource privilege, its consequences for government accountability, and the agents responsible for upholding it; surely, it has at least a small part in the story. But filtering our analysis through the lens of responsiveness prompts us to look beyond the resource privilege, to additional targets for normative assessment. The resource privilege primarily affects leaders' reliance on citizens as a source of revenue; accountability primarily attends to citizens' capacity to

24 This isn't to say that responsiveness is normatively prior to accountability (in some sense of "prior"). Were we to weight social values according to their normative priority, we might give more weight to accountability than to responsiveness precisely because accountability accounts for values beyond responsiveness, such as equality or autonomy. 


\section{David Wiens}

exercise effective voice. An analysis organized around the value of responsiveness attends, in addition, to factors that affect the extent to which resource rich leaders confront citizens with credible exit threats. With respect to this aspect of the curse, attention to responsiveness might lead us to investigate, for example, the extent to which developed countries' immigration policies or (non-resource-related) trade and investment policies reduce the exit options of individuals in resource rich countries and, in turn, undermine government responsiveness. (Citizens' literal exit options are straightforwardly affected by immigration policies; trade and investment policies might affect other types of exit threat by altering the sectoral composition of the economy, influencing the percentage of citizens who hold mobile assets and, hence, possess credible economic exit threats.)

Importantly, attention to responsiveness prompts us to investigate those factors that affect leaders' reliance on citizens and citizens' exit options together rather than in isolation. Exit threats and reliance on citizens work in tandem to induce responsiveness. To be effective, citizens' exit options must empower them to withhold the type of support upon which the government depends. If the government depends on citizens as a source of votes, citizens must be able to re-allocate their votes; enabling citizens to, instead, withhold their money from the government does little to induce responsiveness (unless, of course, the government also relies on citizens as a source of revenue). To the matter at hand, the resource privilege reduces resource rich dictators' reliance on their citizens as a source of revenue; withholding resource revenues from dictators (as Pogge and Wenar propose) should increase their reliance on citizens for revenue. But this does little to improve the prospects for responsiveness (and, in turn, institutional accountability), unless the reforms are coupled with reforms to enhance the economic exit threats of citizens in resource rich countries. ${ }^{25}$ We can't do this by altering the nature of resource assets, so we must look elsewhere. We might look for alternative ways to enhance citizens' economic exit threats to work in tandem with Pogge's or Wenar's sanctions. Or, since our analysis is sensitive to factors beyond the resource privilege, we might instead abandon a sanctions regime in light of its normative costs (Gordon, 1999; Wisor, 2012) and look elsewhere for levers that can affect both resource rich dictators' (not necessarily fiscal)

25 An anonymous reviewer suggests that Pogge and Wenar might avoid my criticism by amending their proposals so that their respective indicators of accountability (Pogge's Democracy Panel and Wenar's Freedom House rating) become sensitive to responsiveness. But the discussion in the main text shows why this simple amendment misses my point. Even with the new responsiveness indicators, Pogge's and Wenar's proposed reforms still emphasize the imposition of trade sanctions, which only affect one factor underlying responsiveness. To address my critical point, Pogge and Wenar would have to propose, in addition, a companion reform that enhances citizens' economic exit threats. 
reliance on citizens and citizens' exit threats. ${ }^{26}$

By revising our targets for normative analysis, a framework centered on responsiveness potentially changes the set of agents that come into view, as well as our attribution of moral responsibility. Pogge's and Wenar's analyses focus on the agents responsible for upholding the resource privilege, whom they deem to be the government and citizens of developed democracies; hence, "we" bear much of the moral responsibility for reforming the resource privilege and mitigating the consequences of the resource curse. But the model in section 3 shows that unaccountable governance and its associated miseries might very well persist in resource rich countries even if we do implement Pogge's and Wenar's proposed reforms, due to factors that are beyond anyone's control (i.e., the physical characteristics of point-source resource assets). "That might be tragic," Pogge or Wenar might respond, "but at least we will not be undermining accountability and contributing to deprivation by upholding an unjust rule." Of course, Pogge and Wenar can acknowledge that we might have positive obligations to assist those who are deprived as a result of the resource curse, and these will still be in force once we have discharged our obligation to stop contributing to their deprivation; the question of positive obligations is simply beyond the scope of their analyses (Pogge, 2005b: 65f). But this misses my point. A normative assessment of the resource curse that concentrates largely on the consequences of the resource privilege for government accountability (a) neglects the fact that reforming the resource privilege need not make a difference to the prospects for government accountability in resource rich countries, and (b) fails to investigate the full range of ways in which we potentially contribute to the persistence of the curse.

Given my argument in section 3, the resource curse is simply an instance of a more general phenomenon, namely, the absence of responsive government. Once we see this, the scope of our analysis must expand to consider all the ways in which we might contribute to the persistence of unresponsive government in resource rich countries. This will likely prompt us to look beyond the ways in which our relationship to resource transactions and the rules governing them contributes to unresponsive government. Put differently, the aim of our assessment should be to investigate our responsibility for undermining responsiveness in resource rich countries, not simply our responsibility for

26 An anonymous reviewer raises the issue of the baseline level of responsiveness for evaluating alternative reform proposals. My thought is that we evaluate reforms with an eye to a threshold of minimally acceptable political and economic development (though I decline to specify that threshold here). Responsiveness enters our assessment indirectly, as a key determinant of development outcomes. The baseline for comparison is thus the level of responsiveness required to sustain a minimally acceptable level of development. I leave aside the details as this issue is not central to my objective in this paper. 


\section{David Wiens}

keeping resource rich dictators flush with cash. Thus, our assessment of the resource curse must look beyond (and perhaps past) our role in upholding the resource privilege to the myriad ways we potentially inhibit the emergence of responsive government in resource rich countries.

Where, besides the resource privilege, might we look? I've offered two suggestions already - immigration policies and trade and investment policies. We might also look to foreign aid $^{27}$ and sovereign lending policies. But I can't say much more than this here; offering a detailed normative assessment of the resource curse is beyond the scope of this paper. As a prelude to such an assessment, my task has been the modest but necessary one of rebuilding the normative framework that structures our analysis of the resource curse. I've done this by pointing out the ways in which extant empirical and normative analyses are blind to causally salient dimensions of the resource curse. I've also shown that our normative assessment must take a wider view, looking beyond resource transactions and the rules governing them. Our assessment of the resource curse does not necessarily concentrate on the pernicious effects of resource revenues and our role in perpetuating them. Instead, an adequately rich assessment focuses on the factors that inhibit the emergence of responsive government in resource rich countries - whatever those are - and our responsibility for the operation of those factors.

27 A surprising number of resource rich countries receive huge amounts of official development aid, including D.R. Congo, Egypt, Indonesia, Nigeria, and Sudan; see OECD 2008: tables 1.2.7 and 1.2.10. 
Resources and Responsiveness

\section{REFERENCES}

Acemoglu, Daron and James A. Robinson. 2006. Economic Origins of Dictatorship and Democracy. New York: Cambridge University Press.

Auty, Richard, ed. 2001. Resource Abundance and Economic Development. New York: Oxford University Press.

Bates, Robert H. and Da-Hsiang Donald Lien. 1985. "A Note on Taxation, Development, and Representative Government." Politics \& Society 14(1):53-70.

Bueno de Mesquita, Bruce, Alastair Smith, Randolph M. Siverson and James D. Morrow. 2003. The Logic of Political Survival. Cambridge, MA: MIT Press.

Clark, William Roberts, Matt Golder and Sona Golder. 2013. "Power and Politics: Insights from an Exit, Voice, and Loyalty Game.” Manuscript, University of Michigan and Penn State University.

Clark, William Roberts, Matt Golder and Sona N. Golder. 2008. Principles of Comparative Politics. Washington, D.C.: CQ Press.

Clark, William Roberts, Paul Poast, Thomas Flores and Robert R. Kaufman. 2010. "Why Do Autocrats Overachieve? Political Competition and Material Well-Being in Comparative Perspective." Mimeo, University of Michigan and Rutgers University.

Collier, Paul and Anke Hoeffler. 2009. "Testing the Neocon Agenda: Democracy in Resource-Rich Countries." European Economic Review 53:293-308.

Dunning, Thad. 2008. Crude Democracy: Natural Resource Wealth and Political Regimes. New York: Cambridge University Press.

Gerring, John, Philip Bond, William T. Barndt and Carola Moreno. 2005. "Democracy and Economic Growth: A Historical Perspective.” World Politics 57:323-364.

Gordon, Joy. 1999. “A Peaceful, Silent, Deadly Remedy: The Ethics of Economic Sanctions.” Ethics \& International Affairs 13(1):123-142.

Hirschman, Albert O. 1970. Exit, Voice, and Loyalty: Responses to Declines in Firms, Organizations, and States. Cambridge, MA: Harvard University Press.

Humphreys, Macartan, Jeffrey D. Sachs and Joseph E. Stiglitz, eds. 2007. Escaping the Resource Curse. New York: Columbia University Press. 
Jensen, Nathan and Leonard Wantchekon. 2004. "Resource Wealth and Political Regimes in Africa." Comparative Political Studies 37(7):816-841.

Karl, Terry Lynn. 1997. The Paradox of Plenty: Oil Booms and Petro-States. Berkeley and Los Angeles: University of California Press.

Levi, Margaret. 1988. Of Rule and Revenue. Berkeley and Los Angeles: University of California Press.

Mahdavy, Hussein. 1970. The Patterns and Problems of Economic Development in Rentier States: The Case of Iran. In Studies in Economic History of the Middle East, ed. M. A. Cook. London: Oxford University Press.

Mehlum, Halvor, Karl Moene and Ragnar Torvik. 2006. "Institutions and the Resource Curse." The Economic Journal 116(1):1-20.

Morrison, Kevin M. 2007. "Natural Resources, Aid, and Democratization: A Best-Case Scenario.” Public Choice 131:365-386.

Morrison, Kevin M. 2009. "Oil, Nontax Revenue, and the Redistributional Foundations of Regime Stability.” International Organization 63:107-138.

Myerson, Roger B. 2008. "The Autocrat's Credibility Problem and Foundations of the Constitutional State." American Political Science Review 102(1):125-139.

North, Douglass C. and Barry Weingast. 1989. "Constitutions and Commitment: The Evolution of Institutions Governing Public Choice in Seventeenth-Century England.” Journal of Economic History 49(4):803-832.

OECD. 2008. “Development Aid at a Glance.” Organisation for Economic Co-operation and Development.

Pogge, Thomas W. 2005a. "Real World Justice.” The Journal of Ethics 9:29-53.

Pogge, Thomas W. 2005b. "Severe Poverty as a Violation of Negative Duties." Ethics \& International Affairs 19(1):55-83.

Pogge, Thomas W. 2007. Severe Poverty as a Human Rights Violation. In Freedom From Poverty as a Human Right: Who Owes What to the Very Poor?, ed. Thomas W. Pogge. New York: Oxford University Press.

Pogge, Thomas W. 2008. World Poverty and Human Rights. 2nd ed. Malden, MA: Polity Press. 
Resources and Responsiveness

Robinson, James A., Ragnar Torvik and Thierry Verdier. 2006. "Political Foundations of the Resource Curse.” Journal of Development Economics 79(2):447-468.

Ross, Michael L. 2001. “Does Oil Hinder Democracy?” World Politics 53:325-361.

Ross, Michael L. 2004. “Does Taxation Lead to Representation?” British Journal of Political Science 34(2):229-249.

Sachs, Jeffrey D. and Andrew M. Warner. 1995. "Natural Resource Abundance and Economic Growth.” NBER Working Paper Series (5398).

Smith, Benjamin. 2006. "The Wrong Kind of Crisis: Why Oil Booms and Busts Rarely Lead to Authoritarian Breakdown.” Studies in Comparative International Development 40(4):55-76.

Snyder, Richard and Ravi Bhavnani. 2005. "Diamonds, Blood, and Taxes: A RevenueCentered Framework for Explaining Political Order." Journal of Conflict Resolution 49(4):563-597.

Tilly, Charles. 1992. Coercion, Capital, and European States, AD 990-1992. Revised ed. Malden, MA: Blackwell.

UNDP. 2008. “Human Development Indicies.” United Nations Development Programme.

Wantchekon, Leonard. 2002. "Why do Resource Abundant Countries Have Authoritarian Governments?” Journal of African Finance and Economic Development 5(2):57-77.

Warren, Mark E. 2011. "Voting With Your Feet: Exit-based Empowerment in Democratic Theory." American Political Science Review 105(4):683-701.

Wenar, Leif. 2008. "Property Rights and the Resource Curse." Philosophy \& Public Affairs $36(1): 2-32$.

Wenar, Leif. 2010. Feasible Reform of International Trade in Resources. In Thomas Pogge and His Critics, ed. Alison M. Jaggar. Malden, MA: Polity Press.

Wiens, David. forthcoming. "Natural Resources and Institutional Development." Journal of Theoretical Politics .

Wisor, Scott. 2012. "Property Rights and the Resource Curse: A Reply to Wenar." Journal of Philosophical Research 37:185-204. 
Resources and Responsiveness

\section{Formal Appendix}

\section{BASIC EVL RESOURCE CURSE GAME}

In this appendix, we provide proofs for various results presented in Section 2.1, "Exit, Voice, and Loyalty Resource Curse Game." The structure of the game is depicted in figure 2.

5.1. The Incentive to Use Voice in the EVL Resource Curse Game In our analysis of the game, we restrict our attention to the situation where the asset holder's immediate exit payoff is less than the payoff he would obtain were he to successfully object to the tax hike and have the government reinstate the low tax rate. Without this restriction, the asset holder never has an incentive to object to a tax hike; he would always exit immediately. We now derive condition under which this restriction holds.

Using the outcome labels shown in Figure 1, we need the asset holder's payoff from outcome $\mathrm{O}_{2}$ to be less than his payoff from outcome $\mathrm{O}_{5} \cdot{ }^{28}$ This will be the case if

$$
\left(1-\tau_{H}\right) Y+\sum_{t=1}^{\infty} \delta^{t} E<\left(1-\tau_{L}\right) Y-C+\sum_{t=1}^{\infty} \delta^{t}\left(1-\tau_{L}\right) Y,
$$

which simplifies to the following condition:

$$
C<\left(\tau_{H}-\tau_{L}\right) Y+\sum_{t=1}^{\infty} \delta^{t}\left[\left(1-\tau_{L}\right) Y-E\right]
$$

5.2. Equilibria Assuming $\tau_{L}<\tau_{H}, E<\left(1-\tau_{L}\right) Y, C<\left(\tau_{H}-\tau_{L}\right) Y+\sum_{t=1}^{\infty} \delta^{t}\left[\left(1-\tau_{L}\right) Y-E\right]$ as we do in the main text, there are three subgame perfect Nash equilibria. One occurs when the asset holder lacks a credible exit threat; the two others occur when he has a credible exit threat.

Equilibrium 1. If the asset holder lacks a credible exit threat, $E \leq\left(1-\tau_{H}\right) Y$, then the following is the subgame perfect Nash equilibrium strategy profile. The government implements the tax hike and would ignore any objection from the asset holder were one forthcoming. The asset holder continues to invest following the tax hike and would continue to invest no matter how the government might respond were he to object.

28 The asset holder continues to invest if the government responds to voice by reinstating the low tax rate $\left(O_{5}\right)$ because $E<\left(1-\tau_{L}\right) Y$. 


\section{David Wiens}

Figure 2. Exit, Voice, and Loyalty (EVL) Resource Curse Game

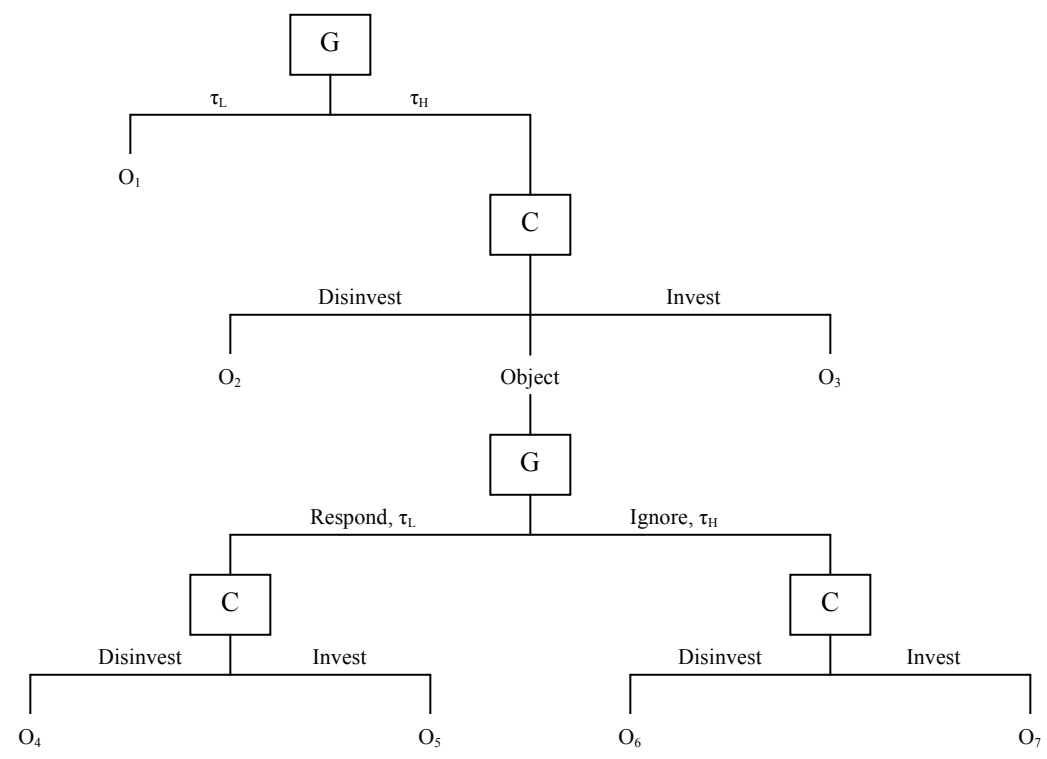

\begin{tabular}{cll|cll} 
Outcome & Government & Asset Holder & Outcome & Government & Asset Holder \\
\hline $\mathrm{O}_{1}$ & $\tau_{L} Y+\sum_{t=1}^{\infty} \delta^{t}\left(\tau_{L} Y\right)$ & $\left(1-\tau_{L}\right) Y+\sum_{t=1}^{\infty} \delta^{t}\left(1-\tau_{L}\right) Y$ & $\mathrm{O}_{5}$ & $\tau_{L} Y+\sum_{t=1}^{\infty} \delta^{t}\left(\tau_{L} Y\right)$ & $\left(1-\tau_{L}\right) Y-C+\sum_{t=1}^{\infty} \delta^{t}\left(1-\tau_{L}\right) Y$ \\
$\mathrm{O}_{2}$ & $\tau_{H} Y$ & $\left(1-\tau_{H}\right) Y+\sum_{t=1}^{\infty} \delta^{t} E$ & $\mathrm{O}_{6}$ & $\tau_{H} Y$ & $\left(1-\tau_{H}\right) Y-C+\sum_{t=1}^{\infty} \delta^{t} E$ \\
$\mathrm{O}_{3}$ & $\tau_{H} Y+\sum_{t=1}^{\infty} \delta^{t}\left(\tau_{H} Y\right)$ & $\left(1-\tau_{H}\right) Y+\sum_{t=1}^{\infty} \delta^{t}\left(1-\tau_{H}\right) Y$ & $\mathrm{O}_{7}$ & $\tau_{H} Y+\sum_{t=1}^{\infty} \delta^{t}\left(\tau_{H} Y\right)$ & $\left(1-\tau_{H}\right) Y-C+\sum_{t=1}^{\infty} \delta^{t}\left(1-\tau_{H}\right) Y$ \\
$\mathrm{O}_{4}$ & $\tau_{L} Y$ & $\left(1-\tau_{L}\right) Y-C+\sum_{t=1}^{\infty} \delta^{t} E$ & & & \\
\hline
\end{tabular}

Note: The game comprises two players: (i) the government, $G$, and (ii) the asset holder, $A$. The asset holder's payoffs depend on his pre-tax income from the first best use of his asset, $Y$; the expected return on the second best use of his asset, $E$; his discount factor, $\delta$; the cost of objecting to any government tax hike, $C$; and whether the tax rate is low, $\tau_{L}$, or high, $\tau_{H}$. The government's payoffs depend on the asset holder's pre-tax income from the first best use of his asset, its discount factor, and the tax rate. We assume that $\tau_{H}>\tau_{L} \geq 0, E<\left(1-\tau_{L}\right) Y$, and that $0<C<\left(\tau_{H}-\tau_{L}\right) Y$. 
Proof. If $E \leq\left(1-\tau_{H}\right) Y$, then

$$
\left(1-\tau_{H}\right) Y+\sum_{t=1}^{\infty} \delta^{t}\left(1-\tau_{H}\right) Y \geq\left(1-\tau_{H}\right) Y+\sum_{t=1}^{\infty} \delta^{t} E
$$

so the asset holder always chooses to invest when confronted with a choice between disinvesting and investing. Recognizing this, the government ignores any objection from the asset holder and maintains the tax hike so long as

$$
\tau_{L} Y+\sum_{t=1}^{\infty} \delta^{t} \tau_{L} Y \leq \tau_{H} Y+\sum_{t=1}^{\infty} \delta^{t} \tau_{H} Y
$$

which is always the case because $\tau_{L}<\tau_{H}$. The fact that objections are costly and will be ignored, combined with the fact that the asset holder lacks a credible exit threat, means that the asset holder responds to a tax hike by continuing to invest at the current rate. Given this, the government chooses to impose the tax hike at the beginning of the game.

Equilibrium 2. If the asset holder has a credible exit threat, $E>\left(1-\tau_{H}\right) Y$, and the government places sufficiently high value on continued investment, $\delta \geq 1-\frac{\tau_{L}}{\tau_{H}}$, then the following is the subgame perfect Nash equilibrium strategy profile. The government does not impose the tax hike and would revert to the low tax rate if the asset holder objects to an increase in the tax rate. The asset holder objects to any tax hike, disinvests if the government ignores his objection, and continues to invest at the current level if the government responds to his objection by reverting to the low tax rate.

Proof. If the government responds positively to an objection by the asset holder and reverts to the low tax rate, the asset holder continues to invest because $E<\left(1-\tau_{L}\right) Y$. If the government ignores an objection by the asset holder and maintains the tax hike, the asset holder disinvests because $E>\left(1-\tau_{H}\right) Y$. Knowing this, the government reverts to the low tax rate following an objection by the asset holder just in case

$$
\tau_{L} Y+\sum_{t=1}^{\infty} \delta^{t}\left(\tau_{L} Y\right) \geq \tau_{H} Y
$$


which simplifies to

$$
\left(\frac{1}{1-\delta}\right) \tau_{L} Y \geq \tau_{H} Y
$$

Solving for $\delta$, we get

$$
\delta \geq 1-\frac{\tau_{L}}{\tau_{H}}
$$

Since this condition holds by assumption, the asset holder objects to any tax hike, since we have assumed that he has a credible exit threat, $E>\left(1-\tau_{H}\right) Y$, and that objecting is not too costly, $C<\left(\tau_{H}-\tau_{L}\right) Y+\sum_{t=1}^{\infty} \delta^{t}\left[\left(1-\tau_{L}\right) Y-E\right]$. Knowing that the asset holder will object to a tax hike and that it will revert to the low tax rate in response, the government is indifferent between maintaining the low tax rate at the beginning of the game and initially imposing the tax hike and then reneging. To avoid knife-edge scenarios, we assume the government maintains the low tax rate from the start when (5) obtains.

Equilibrium 3. If the asset holder has a credible exit threat, $E>\left(1-\tau_{H}\right) Y$, and the government does not place sufficiently high value on continued investment, $\delta<1-\frac{\tau_{L}}{\tau_{H}}$, then the following is the subgame perfect Nash equilibrium strategy profile. The government implements the tax hike and would ignore any objection from the asset holder were one to come. The asset holder disinvests following the tax hike. Were he to make an objection, the asset holder would disinvest if the government ignores the objection and continue to invest if the government responds favorably.

Proof. Suppose (5) does not hold, i.e., $\delta<1-\frac{\tau_{L} Y}{\tau_{H} Y}$. As in Equilibrium 2, the asset holder continues to invest if the government reverts to the low rate following an objection by the asset holder; if the government would ignore his objection, the asset holder disinvests, since he has a credible exit threat, $E>\left(1-\tau_{H}\right) Y$. Since (5) does not hold, the government nevertheless ignores any objection by the asset holder and imposes the tax hike. Since objecting is costly, $C>0$, the asset holder disinvests immediately following a tax hike. Assuming (5) does not hold, the government implements the high rate from the start. 